\title{
Brain FDG-PET Scan and Brain Perfusion SPECT in the Diagnosis of Neuroacanthocytosis Syndromes
}

\author{
Nöroakantositoz Sendromlarının Tanısında Beyin FGD-PET Görüntüleme ve Beyin \\ Perfüzyon SPECT
}

\section{Eylem Değirmenci', Doğangün Yüksel2}

I Pamukkale University Faculty of Medicine, Department of Neurology, Denizli, Turkey

2Pamukkale University Faculty of Medicine, Department of Nuclear Medicine, Denizli, Turkey

\begin{abstract}
Neuroacanthocytosis syndromes (NA) include autosomal recessive chorea-acanthocytosis and X-linked McLeod syndrome consisting of a choreatic movement disorder, psychiatric manifestations and cognitive decline, and additional multi-system features including myopathy and axonal neuropathy. Fluor 18 -2-fluoro-2-deoxyglucose (18F-FDG-PET) positron emission tomography (PET) and technetium 99m -d, I-hexamethyl-propylene amine oxime (99mTc-HMPAO) brain single photon emission computed tomography (SPECT) have been increasingly used for the detection of neurologic disorders, such as dementia, epilepsy, and movement disorders. In this case report, we report two patients with neuroacanthocytosis syndromes with the imaging features of brain metabolism by PET and brain perfusion by SPECT. Brain PET and brain SPECT findings of patients with neuroacanthocytosis syndromes were also reviewed.
\end{abstract}

Key Words: Chorea-acanthocytosis, McLeod syndrome, neuroacanthocytosis, PET, SPECT

Conflicts of Interest: The authors reported no conflict of interest related to this article.

\section{Özet}

Nöroakontozis sendromları (NA) koreik hareket bozukluğu, psikiyatrik bulgular ve kognitif düşüş ve miyopati ve aksonal nöropatiyi içine alan ilave çoklu sistem tutulumundan oluşan otozomal resesif kore-akantozis ve X-linked McLeod sendromundan oluşur. Fluor 18-2-fluoro-2-deoxyglucose (18F-FDG) pozitron emisyon tomografi (PET) ve technetium 99m -d, I-hexamethyl-propylene amine oxime (99mTc-HMPAO) beyin single photon emission computed tomography (SPECT) demans, epilepsi ve hareket hastalıkları gibi nörolojik hastalıkların saptanmasında artan şekilde kullanılmaktadır. Bu olgu sunumunda, biz beyin metabolizma PET ve beyin perfüzyon SPECT görüntüleme bulguları olan nöroakantozisli iki hastayı rapor ediyoruz. Ek olarak nöroakantozis sendromlu hastalardaki beyin PET ve beyin SPECT bulguları gözden geçirildi.

Anahtar Kelimeler: Kore-akantozis, McLeod sendromu, nöroakantozis, PET, SPECT

Çıkar Çatışması: Yazarlar bu makale ile ilgili olarak herhangi bir çıkar çatışması bildirmemiştir.

\section{Introduction}

Neuroacanthocytosis is a rare movement disorder characterized by progressive muscle weakness and atrophy, progressive cognitive loss, chorea, and acanthocytosis (1). Acanthocytes, abnormal thorny red blood cells (RBC), are one of the biological hallmarks of neuroacanthocytosis syndromes (NA) that is a group of rare hereditary neurodegenerative disorders (2).

Address for Correspondence: Eylem Değirmenci MD, Pamukkale University Faculty of Medicine, Department of Neurology, Denizli, Turkey Phone: +90 44407 28-5677 E-mail: eylemteke@yahoo.com Received: 17.04.2013 Accepted: 19.06.2013 
Neuroacanthocytosis syndromes are exceptionally rare with an estimated prevalence of less than 1 to 5 per 1000 000 inhabitants for each disorder. The core NA syndromes include autosomal recessive chorea-acanthocytosis and X-linked McLeod syndrome which have a Huntington's disease-like phenotype consisting of a choreatic movement disorder, psychiatric manifestations and cognitive decline, and additional multi-system features including myopathy and axonal neuropathy. Additionally there are several genetically defined disorders in which acanthocytosis is occasionally seen, such as pantothenate kinase-associated neurodegeneration (PKAN) and Huntington disease-like 2 (HDL2) (2).

Fluor 18 -2-fluoro-2-deoxyglucose (18F-FDG-PET) positron emission tomography (PET) and technetium 99m -d, I-hexamethyl-propylene amine oxime (99mTc-HMPAO) brain single photon emission computed tomography (SPECT) have been increasingly used for the detection of neurologic disorders, such as dementia, epilepsy, and movement disorders. In this article, we report two patients with neuroacanthocytosis syndromes with the imaging features of brain metabolism by PET and brain perfusion by SPECT. In addition brain PET and brain SPECT findings of patients with neuroacanthocytosis syndromes were reviewed.

\section{Case Reports}

\section{Patient 1}

A 29-year-old male patient who had a 2-year history of dysarthria, dysphasia, lip biting and chorea of the trunk and limbs was previously admitted to psychiatry clinics, and was referred to our department for evaluation of neurologic pathologies. His gestation, delivery, and early developmental milestones were unremarkable. The neurological examination revealed a complex hyperkinetic disorder including generalized chorea, orofacial dyskinesias, dysarthria with slurred speech, dysphonia, and minimal dysdiadochokinesia. The gait was bizarre due to both choreatic and dystonic components. Further neurological, general and psychiatric examinations were normal. The patient's serum creatine kinase (CK) level was $1585 \mathrm{U} / \mathrm{L}$ (Normal range: 20-200 U/L), myoglobulin was $198.3 \mathrm{ng} / \mathrm{ml}$ (Normal range: 0-110 ng/ml), and serum coeruloplasmin, copper, serum lipoprotein electrophoresis, and vitamin E levels were within normal limits. Peripheral blood smear showed 3-5\% acanthocytosis. His EEG showed right temporal paroxysmal activity, and the patient's needle electromyography and nerve conduction velocities were unremarkable. Cardiac examination and echocardiography were also normal. The patient's magnetic resonance imaging (MRI) of the brain which was performed in 1.5 Tesla MR system with axial T1weighted, T2-weighted, axial proton density, axial fluid attenuation inversion recovery (FLAIR) and axial and coronal gadolinium-enhanced T1-weighted images was normal (Figure 1).
On the 18F-FDG-PET images of the patient, no 18F-FDG uptake was observed visually in both caudate nuclei. There was minimal 18F-FDG uptake in both lentiform nuclei. The activity uptake of the left lentiform nucleus was less than that of the right side (Figure 2). In the quantitative analysis, hypometabolic areas were identified in the left caudate nucleus, left lentiform nucleus, right caudate nucleus and left lentiform nucleus. The standard deviations from the mean of asymptomatic control group of NeuroQ were $-5.4108,-3.4497,-3.2298$ and -1.6914 , respectively (Figure 3).

\section{Patient 2}

A 35-year-old male patient, whose cousin was suffering from similar complaints such as involuntary movements, lip biting, feeding difficulties, involuntary vocalizations, and left sided choreatic movement with dystonic component was admitted to our hospital. His gestation, delivery, and early developmental milestones were unremarkable until age 30. The neurological examination revealed a complex hyperkinetic disorder including left sided chorea, orofacial dyskinesias, dysarthria with slurred speech, dysphonia, sudden flexion and extension movements of the left arm, dysdiadochokinesia, dystonia, and vocalizations with different noises such as snoring, snorting, nonsense words, and the syllable "hap". Hyperkinetic movements were more prominent on the left part of the body. Reflexes were absent and muscle tonus was reduced. Further neurological examinations were normal but cardiac examination and echocardiography revealed global akinesia and left ventricular myocardial bands. Psychiatric examination showed cognitive impairment, depression, and self-neglect. The patient's CK level was $502 \mathrm{U} / \mathrm{L}$, serum ceruloplasmin, copper, serum lipoprotein electrophoresis, vitamin E levels were within normal limits. Peripheral blood smear showed

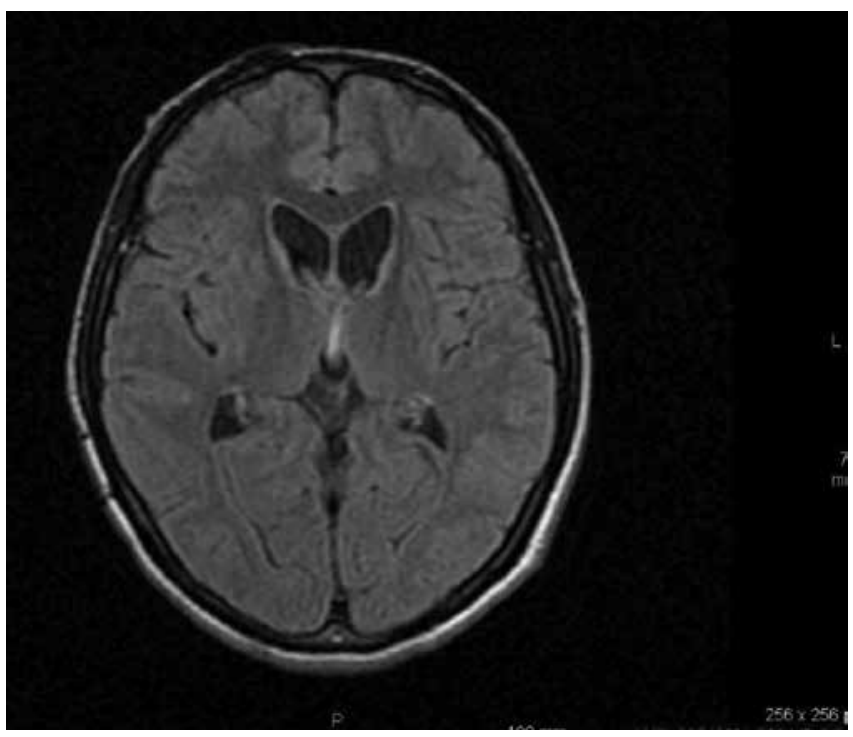

Figure 1. Axial fluid attenuation inversion recovery magnetic resonance image showing normal brain 
1-3\% acanthocytosis. His EEG, needle electromyography and nerve conduction velocities were unremarkable.

The patient's MRI of the brain which was performed in 1.5 Tesla MR system with axial T1-weighted, T2-weighted, axial proton density, FLAIR and axial and coronal gadoliniumenhanced T1-weighted images showed irregularity of bilateral caudate, putamen and globus pallidus nuclei (Figure 4). 99mTC-HMPAO SPECT showed hypoperfusion in the right lentiform nucleus (Figure 5).

Both patients' genetic consultations were also performed but genetic analyses for the definite diagnosis of neuroacanthocytosis syndromes could not be performed. The patients were put on tetrabenazine treatment with the diagnosis of neuroacanthocytosis syndromes and showed minimal clinical improvement.

\section{Literature Review and Discussion}

The terms "neuroacanthocytosis syndromes+PET" and "neuroacanthocytosis syndromes+SPECT", "neuroacanthocytosis+PET", "neuroacanthocytosis+SPECT", "chorea-acanthocytosis+PET", "chorea-acanthocytosis+SPECT", "Mc-

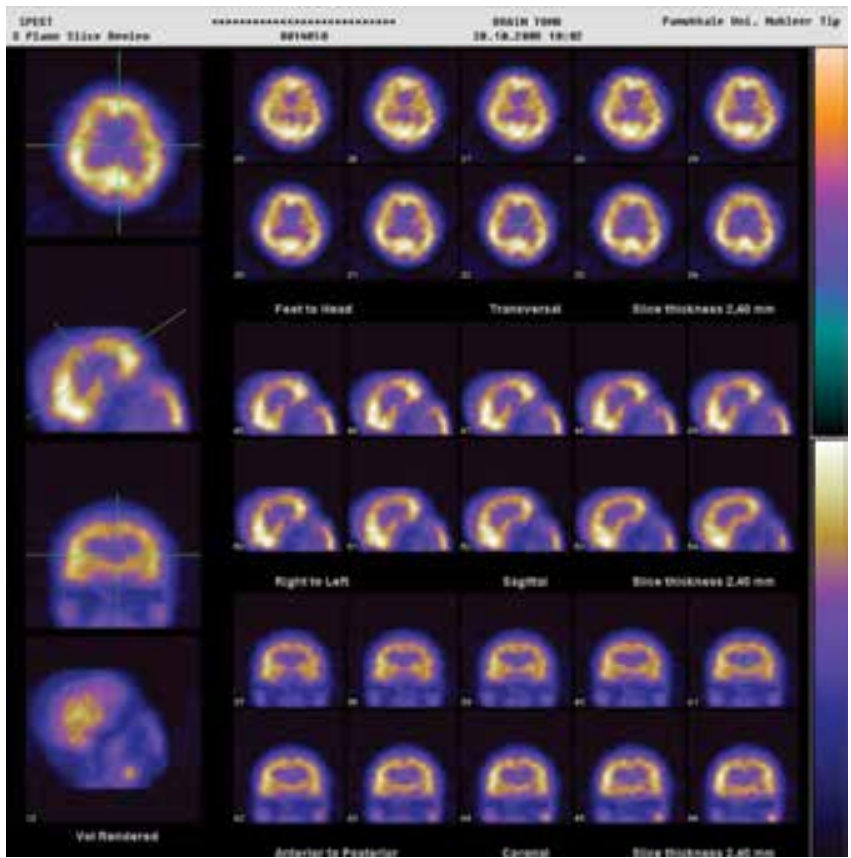

Figure 2. The PET study was performed with the subjects' eyes open in a dimly lit room and with minimal auditory stimulation. Written consent was obtained from each subject after detailed explanation of the procedures. PET data were acquired using a Philips Gemini TF PET/CT 16-Scanner (Philips Medical Systems, Cleveland, Ohio, USA) (18 cm axial field of view; $4.7 \mathrm{~mm}$ axial resolution) 50 min. after the intravenous injection of $221 \mathrm{MBq}$ of FDG. Data were corrected for both scatter and measured attenuation, which was determined by using the CT scan for PET/CT scanner. The 18F-FDG-PET transaxial images of the patient did not reveal $18 \mathrm{~F}$-FDG uptake visually in both caudate nuclei. There was minimal 18 F-FDG uptake in both lentiform nuclei The activity uptake of the left lentiform nucleus was less than that of the right side
Leod Syndrome+PET", and "McLeod Syndrome+SPECT" were searched in the US National Library of Medicine National Institutes of Health-Pubmed. After examining the all results, a total of 11 manuscripts were evaluated $(3,4,5,6,7,8,9,10,11,12,13)$. Table 1 summarizes the articles according to the number and diagnosis of cases, tech-

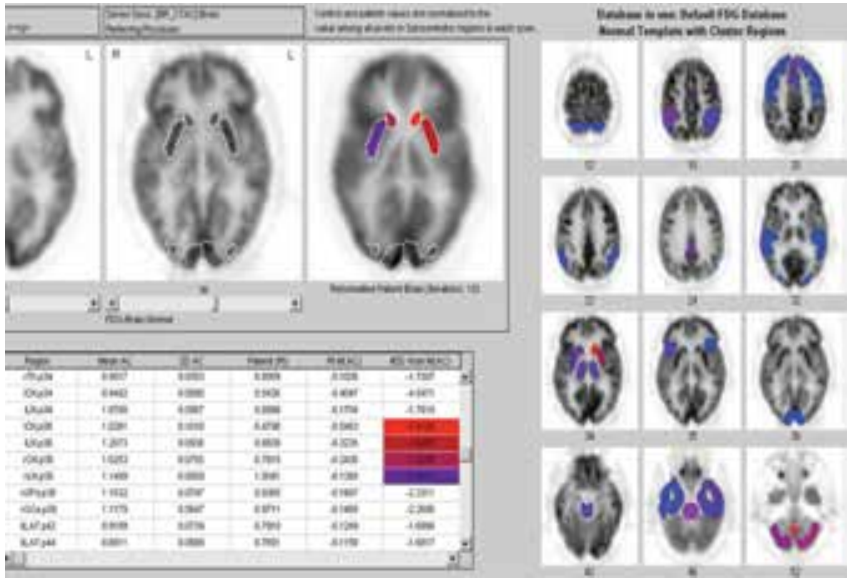

Figure 3. Reorientation was applied to 18 F-FDG PET brain data. Reoriented image was quantified by NeuroQ program (Philips Medical Systems, Cleveland, Ohio, USA). Areas of less than 1.65 SD were accepted as hypometabolic areas. Because cerebellum, pons, thalamus uptake were visually lower than expected, control and patient values were normalized to the value among all pixels in sensory-motor regions in each scan in the quantitative analysis. In the quantitative analysis, hypometabolic areas were identified as the left caudate nucleus (ICN), left lentiform nucleus (ILN), right caudate nucleus ( $\mathrm{rCN}$ ) and right lentiform nucleus (rLN). The standard deviations from the mean of asymptomatic control group of NeuroQ were $-5.4108,-3.4497,-3.2298$ and -1.6914 , respectively

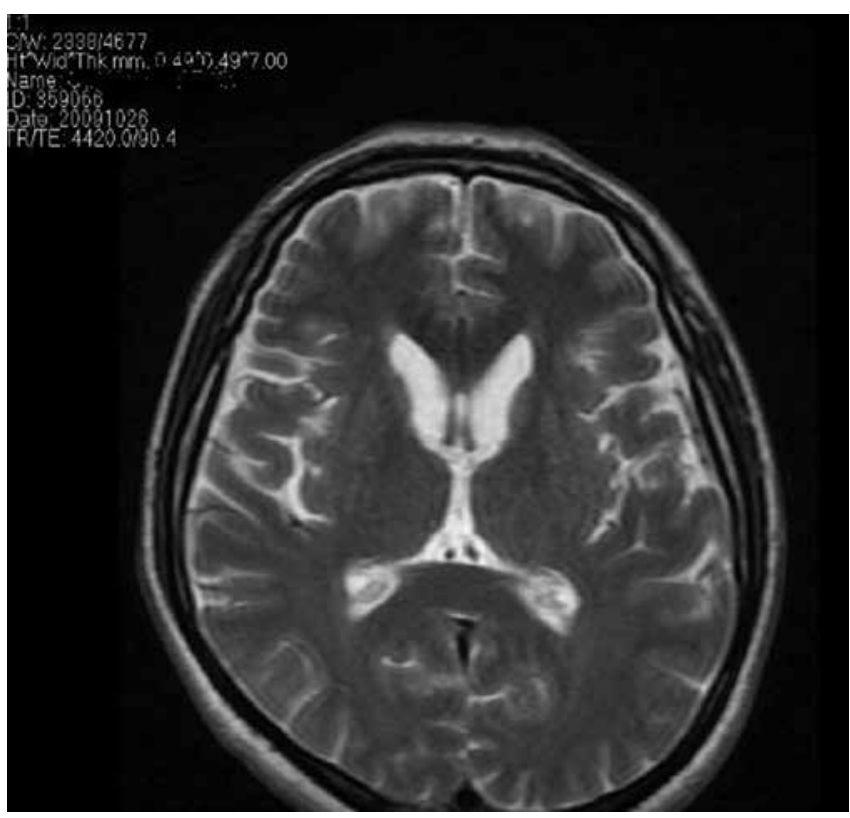

Figure 4. Axial T2-weighted magnetic resonance image showing irregularity of bilateral caudate, putamen and globus pallidus nuclei 
nique used by nuclear medicine clinics, as well as the results of PET and/or SPECT scans.

Regional brain glucose metabolism in neuroacanthocytosis was first described by Dubinsky et al. (3), and his patients' MRI were normal similar to one of our patients presented herein (case 1). The visual interpretation of the cerebral MRI was reported to be normal in a patient with McLeod syndrome with cerebral involvement by Jung et al. However, visual interpretation of the PET scans, and analysis of region-of-interest values that provided z-scores of less than 2 were also reported to be normal in their patient (12). In case 1, clinical signs and symptoms of cerebral involvement were more prominent and 18F-FDGPET scan showed no FDG in the caudate nuclei. Therefore, utilization of different neuroimaging techniques would be helpful to detect disease involvement, especially in asymptomatic cases.

A study by Müller-Vahl et al. evaluated glucose metabolism of monozygotic twins with choreaacanthocytosis, and global glucose metabolic rates were

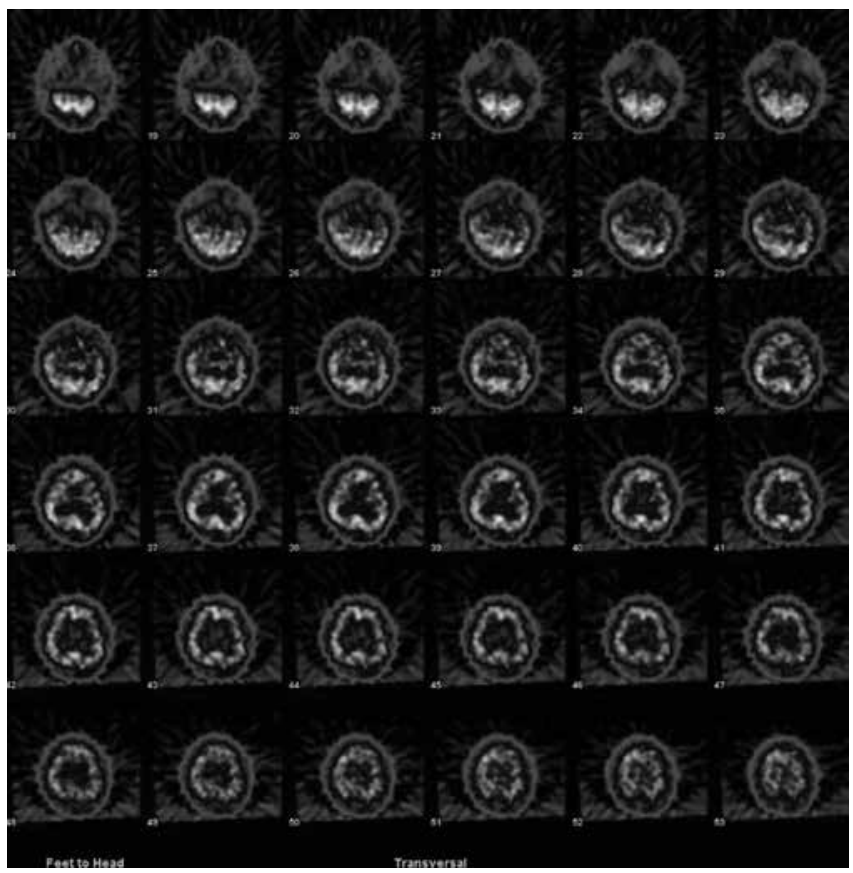

Figure 5. The patient rested in the supine position, with closed eyes, within a silent and darkened room for approximately $20 \mathrm{~min}$. 99mTc- HMPAO was prepared according to the manufacturer's instructions and $550 \mathrm{MBq}$ of 99mTc- HMPAO was injected through an IV canula. The SPECT study was performed $30 \mathrm{~min}$. after injection. A single-head 360 degree rotating CamStar AC/T gamma camera (GE, Milwaukee, Wisc., USA) equipped with a LEAP collimator was used for SPECT acquisition. The patient's head was fixed in a plastic head holder apparatus to minimize motion artifacts. Data were obtained in $128 \times 128$ matrices, 1.6 zoom and at 3 degree intervals for $20 \mathrm{sec} /$ frame. Hamming filter (0.7:0.54) was used for reconstruction of SPECT data. Attenuation correction was not performed. Trans-axial and sagittal images of 99mTc-HMPAO SPECT showed hypoperfusion in the right lentiform nucleus found normal in both twins. However, glucose uptake was relatively reduced in the striatum of both patients. The clusters of relative decrease in uptake were significantly different between twins, and they concluded that this result would be attributed to other environmental factors rather than genetic factors (9).

99mTc HMPAO SPECT showed hypoperfusion in the right lentiform nucleus in case 2. Bilateral striatal hypometabolism in 18F-FDG-PET, and hypoperfusion in $99 \mathrm{mTC}$ HMPAO SPECT was also previously reported in a case of chorea-acanthocytosis (10). Müler-Vahl et al. reported reduced striatal dopamine transporter binding on the right side, in one of the twins by 123/-2-b-carbomethoxy-3-b-(4iodophenyl)-tropane (123|-b-CIT) single photon emission computed tomography 123|BZM-SPECT (123|BZM-SPECT) scans (9). We think these different results can be explained by the wide spectrum of neuroacanthocytosis syndromes and different techniques used by nuclear medicine clinics.

Combined positron-emission tomography and MRI studies may improve diagnostic accuracy in patients with neuroacanthocytosis syndromes. Peppard et al. reported two patients with parkinsonism and neuroacanthocytosis whose 18F-FDG PET scans showed nigrostriatal deficit. They also reported that these two patients responded well to dopaminomimetic therapy (4). As neuroacanthocytosis syndromes can present with variable symptoms, use of different neuroimaging techniques may be helpful in both confirming the diagnosis and deciding on symptomatic treatment.

Sydenham chorea is one of the most common causes of choreatic diseases that shows striatal hypermetabolism on PET-CT images (14). In our cases, the ratio of acanthocytosis was fewer than $5 \%$, and although they had some clinical clues to diagnosis, the differential diagnosis of choreatic movement disorders characterized by basal ganglia hypermetabolism such as autoimmune causes or Sydenham chorea could be achieved by the information gained from both PET and SPECT examinations.

In summary, nuclear medicine techniques used for evaluating brain activity in patients with choreaneuroacantocytosis syndromes include SPECT studies using 123/-IMP, 123|-IBZM, 99mTC-ECD HMPAO SPECT, and PET studies by 18F-FDG PET and PET with oxygen-15 steady state technique. Reduced striatal metabolism is the most common finding in 18F-FDG PET studies. In addition, Saiki et al. also reported hypometabolism of the frontal cortex in patients with chorea-acanthocytosis (7). Reduced striatal dopamine D2-receptor binding is the common finding in all SPECT studies. When all case reports are assessed together; it is difficult to claim existence of a strong correlation between clinical signs and PET and/or SPECT findings. Further case reports and studies would be helpful to understand the clinical utility of PET and/or SPECT in patients with neuroacanthocytosis syndromes. 
Table 1. The number and diagnosis of cases, technique used by nuclear medicine clinics, the results of PET and/or SPECT scans

\begin{tabular}{|c|c|c|c|c|}
\hline References & $\begin{array}{l}\text { Number of } \\
\text { Cases }\end{array}$ & $\begin{array}{l}\text { Definite } \\
\text { Diagnosis }\end{array}$ & $\begin{array}{l}\text { Imaging } \\
\text { Techniques }\end{array}$ & Findings \\
\hline $\begin{array}{l}\text { Dubinsky et al.; Regional } \\
\text { brain glucose metabolism in } \\
\text { neuroacanthocytosis }\end{array}$ & 2 & Neuroacanthocytosis & 18F-FDG PET & $\begin{array}{l}\text { Glucose hypometabolism of the } \\
\text { caudate and putamen }\end{array}$ \\
\hline $\begin{array}{l}\text { Peppard et al.; Parkinsonism with } \\
\text { neuroacanthocytosis }\end{array}$ & 2 & Neuroacanthocytosis & 18F-FDG PET & Nigrostriatal hypometabolism \\
\hline $\begin{array}{l}\text { Selcuk et al.; Reduction of glucose } \\
\text { metabolism in basal ganglia } \\
\text { diagnosed with FDG-PET scan: a } \\
\text { neuroacanthocytosis case }\end{array}$ & 1 & Neuroacanthocytosis & 18F-FDG PET & $\begin{array}{l}\text { No metabolism in the bilaterally } \\
\text { caudate nuclei and putamen. }\end{array}$ \\
\hline $\begin{array}{l}\text { Delecluse et al.; Frontal } \\
\text { impairment and hypoperfusion in } \\
\text { neuroacanthocytosis }\end{array}$ & 1 & Neuroacanthocytosis & $\begin{array}{l}\text { 99mTc HMPAO } \\
\text { SPECT }\end{array}$ & $\begin{array}{l}\text { Hypoperfusion in both frontal lobes } \\
\text { and slight flow decrease in the caudate } \\
\text { nuclei }\end{array}$ \\
\hline $\begin{array}{l}\text { Saiki et al.; Chorea-acanthocytosis } \\
\text { associated with Tourettism }\end{array}$ & 2 & $\begin{array}{l}\text { Chorea- } \\
\text { acanthocytosis }\end{array}$ & 18F-FDG PET & $\begin{array}{l}\text { Hypometabolism of the striatum and } \\
\text { mild hypometabolism of the frontal } \\
\text { cortex }\end{array}$ \\
\hline $\begin{array}{l}\text { Tanaka et al.; Cerebral hypoperfusion } \\
\text { and hypometabolism with altered } \\
\text { striatal signal intensity in chorea- } \\
\text { acanthocytosis: a combined PET and } \\
\text { MRI study }\end{array}$ & 3 & $\begin{array}{l}\text { Chorea- } \\
\text { acanthocytosis }\end{array}$ & $\begin{array}{l}\text { PET with } \\
\text { oxygen-15 } \\
\text { steady state } \\
\text { technique }\end{array}$ & $\begin{array}{l}\text { Reduced regional cerebral blood flow } \\
\text { and oxygen metabolism in the caudate } \\
\text { nuclei and putamen }\end{array}$ \\
\hline $\begin{array}{l}\text { Müller-Vahl et al.; Chorea- } \\
\text { acanthocytosis in monozygotic } \\
\text { twins: clinical findings and } \\
\text { neuropathological changes as } \\
\text { detected by diffusion tensor imaging, } \\
\text { FDG-PET and (123) I-beta-CIT-SPECT }\end{array}$ & 2 & $\begin{array}{l}\text { Chorea- } \\
\text { acanthocytosis }\end{array}$ & $\begin{array}{l}\text { 18F-FDG PET and } \\
\text { 123|BZM-SPECT }\end{array}$ & $\begin{array}{l}\text { PET: Bilaterally reduced glucose } \\
\text { utilization in the striatum } \\
\text { SPECT: Reduced striatal dopamine } \\
\text { transporter binding on the right side in } \\
\text { twin } 1\end{array}$ \\
\hline $\begin{array}{l}\text { Bader et al.; Bilateral temporal lobe } \\
\text { epilepsy confirmed with intracranial } \\
\text { EEG in chorea-acanthocytosis }\end{array}$ & 1 & $\begin{array}{l}\text { Chorea- } \\
\text { acanthocytosis }\end{array}$ & $\begin{array}{l}\text { 18F-FDG PET } \\
\text { 99mTC HMPAO } \\
\text { SPECT }\end{array}$ & $\begin{array}{l}\text { Bilaterally hypometabolism in the } \\
\text { striatum }\end{array}$ \\
\hline $\begin{array}{l}\text { Oechsner et al.; Reduction of striatal } \\
\text { glucose metabolism in McLeod } \\
\text { choreoacanthocytosis }\end{array}$ & 2 & McLeod Syndrome & $\begin{array}{l}\text { 18F-FDG PET and } \\
\text { 123|BZM-SPECT }\end{array}$ & $\begin{array}{l}\text { PET: Reduced metabolism in the } \\
\text { striatum which was significant in one of } \\
\text { the patients } \\
\text { SPECT: Diffuse reduction of dopamine } \\
\text { D2 binding sites in the region of } \\
\text { bilateral caudate nuclei and putamen in } \\
\text { one patient }\end{array}$ \\
\hline $\begin{array}{l}\text { Jung et al.; McLeod phenotype } \\
\text { associated with a XK missense } \\
\text { mutation without hematologic, } \\
\text { neuromuscular, or cerebral } \\
\text { involvement }\end{array}$ & 1 & McLeod Syndrome & 18F-FDG PET & Normal \\
\hline $\begin{array}{l}\text { Danek et al.; Cerebral involvement in } \\
\text { McLeod syndrome }\end{array}$ & 1 & McLeod syndrome & 123I-IMP SPECT & $\begin{array}{l}\text { Reduced striatal dopamine D2-receptor } \\
\text { binding }\end{array}$ \\
\hline
\end{tabular}

${ }^{18}$ F-FDG PET: ( ${ }^{18 F}$ F-2-fluoro-2-deoxyglucose PET scan, ${ }^{123}$-IMP-SPECT: N-isopropyl-4-(123|) iodoamphetamine single photon emission computed tomography, ${ }^{123}$ |BZZM-SPECT: 123-2-b-carbomethoxy-3-b-(4-iodophenyl)-tropane ( ${ }^{123}$-b-CIT) single photon emission computed tomography, 99mTc HMPAO SPECT: Cerebral blood flow tomography, by xenon 133 inhalation or technetium 99m HMPAO (99mTc-d, I-hexamethyl-propylene amine oxime) injection single photon emission computed tomography 


\section{References}

1. Jung HH, Danek A, Walker RH. Neuroacanthocytosis syndromes. Orphanet J Rare Dis 2011;6:68.

2. De Franceschi L, Scardoni G, Tomelleri C, Danek A, Walker RH, Jung HH, Bader B, Mazzucco S, Dotti MT, Siciliano A, Pantaleo A, Laudanna C. Computational identification of phospho-tyrosine subnetworks related to acanthocyte generation in neuroacanthocytosis. PLoS One 2012;7:310-315.

3. Dubinsky RM, Hallett M, Levey R, Di Chiro G. Regional brain glucose metabolism in neuroacanthocytosis. Neurology 1989;39:1253-1255.

4. Peppard RF, Lu CS, Chu NS, Teal P, Martin WR, Calne DB. Parkinsonism with neuroacanthocytosis. Can J Neurol Sci 1990;17:298-291.

5. Selcuk NA, Fenercioglu A. Reduction of glucose metabolism in basal ganglia diagnosed with FDG-PET scan: a neuroacanthocytosis case. Clin Nucl Med 2010:35:557-558

6. Delecluse F, Deleval J, Gérard JM, Michotte A, Zegers de Beyl D. Frontal impairment and hypoperfusion in neuroacanthocytosis. Arch Neurol 1991;48:232-234

7. Saiki S, Hirose G, Sakai K, Matsunari I, Higashi K, Saiki M, Kataoka S, Hori A, Shimazaki K. Chorea-acanthocytosis associated with Tourettism. Mov Disord 2004;19:833-836.
8. Tanaka M, Hirai S, Kondo S, Sun X, Nakagawa T, Tanaka S, Hayashi K, Okamoto K. Cerebral hypoperfusion and hypometabolism with altered striatal signal intensity in chorea-acanthocytosis: a combined PET and MRI study. Mov Disord 1998;13:100-107.

9. Müller-Vahl KR, Berding $G$, Emrich HM, Peschel T. Choreaacanthocytosis in monozygotic twins: clinical findings and neuropathological changes as detected by diffusion tensor imaging, FDG-PET and (123)I-beta-CIT-SPECT. J Neurol 2007;254:1081-1088.

10. Bader $B$, Vollmar $C$, Ackl N, Ebert $A$, la Fougère $C$, Noachtar $S$, Danek A. Bilateral temporal lobe epilepsy confirmed with intracranial EEG in chorea-acanthocytosis. Seizure 2011;20:340-342.

11. Oechsner M, Buchert R, Beyer W, Danek A. Reduction of striatal glucose metabolism in McLeod choreoacanthocytosis. J Neurol Neurosurg Psychiatry 2001;70:517-520.

12. Jung $H H$, Hergersberg $M$, Vogt $M$, Pahnke J, Treyer $V$, Röthlisberger $B$, Kollias SS, Russo D, Frey BM. McLeod phenotype associated with a XK missense mutation without hematologic, neuromuscular, or cerebral involvement. Transfusion 2003;43:928-938.

13. Danek A, Uttner I, Vogl T, Tatsch K, Witt TN. Cerebral involvement in McLeod syndrome. Neurology 1994;44:117-120.

14. Ho L. Hypermetabolism in bilateral basal ganglia in Sydenham chorea on F-18 FDG PET-CT. Clin Nucl Med 2009;34:114-116. 